\title{
Identifikasi Kebutuhan Fasilitas Bagi Penumpang di Stasiun Kereta Api Berdasarkan Analisis Pergerakan Penumpang
}

\author{
Identification of Station Facilities Needed by Train Passenger Based \\ on Passenger Movement Analysis
}

\author{
Anita Susanti $^{1, a)}$, Ria Asih Aryani Soemitro ${ }^{2, b)}$ \& Hitapriya Suprayitno, ${ }^{2, c)}$ \\ ${ }^{1)}$ Mahasiswa Teknik Sipil, Institut Teknologi Sepuluh Nopember, Surabaya \\ ${ }^{2)}$ Departemen Teknik Sipil, Institut Teknologi Sepuluh Nopember, Surabaya
}

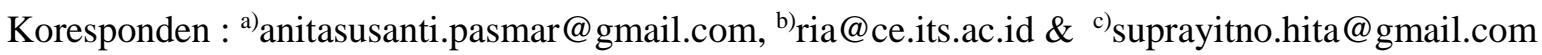

\begin{abstract}
ABSTRAK
Infrastruktur adalah komponen penting yang harus direncanakan, dirancang, dibangun, dan dikelola dengan baik sesuai dengan prinsip-prinsip Manajemen Aset Infrastruktur. Salah satu infrastruktur transportasi yang penting adalah ketersediaan fasilitas di stasiun Kereta Api (KA). Oleh karena itu diperlukan penelitian mengenai identifikasi kebutuhan fasilitas bagi penumpang di stasiun KA berdasarkan analisis pergerakan penumpang. Metode yang dilakukan pada penelitian ini adalah pengamatan langsung di stasiun KA terkait pergerakan penumpang KA Komuter di stasiun asal dan stasiun tujuan. Hasil penelitian diketahui bahwa proses tiba di stasiun asal membutuhkan adanya ketersediaan tipe fasilitas seperti halnya fasilitas penyeberangan, trotoar, bus stop, fasilitas bagi pejalan kaki, parkir kendaraan, drop zone. Proses untuk dapat menggunakan KA Komuter di stasiun asal membutuhkan ketersediaan tipe fasilitas seperti halnya loket, tempat duduk, toilet, pintu masuk, kantin, mushola, fasilitas charger, hall, peron, tangga naik ke KA. Proses turun dari KA membutuhkan adanya ketersediaan tipe fasilitas seperti halnya tangga turun dari KA, peron, toilet, hall, pintu keluar, embarking yang harus disediakan di stasiun tujuan. Proses keluar dari stasiun tujuan membutuhkan adanya ketersediaan tipe fasilitas seperti halnya fasilitas bagi pejalan kaki, parkir kendaraan, parkir khusus bagi penjemput, taksi stand, gojek stand, trotoar, bus stop, fasilitas penyeberangan, terminal yang harus disediakan di stasiun tujuan.
\end{abstract}

Kata Kunci : manajemen aset infrastruktur, stasiun kereta api, fasilitas, pergerakan penumpang

\section{PENDAHULUAN}

Infrastruktur adalah komponen penting yang harus direncanakan, dirancang, dibangun, dan dikelola dengan baik sesuai dengan prinsip-prinsip Manajemen Aset Infrastruktur. Salah satu infrastruktur transportasi yang penting adalah stasiun Kereta Api (KA). Stasiun KA adalah tempat untuk menaikkan dan menurunkan penumpang. Penumpang dalam menggunakan layanan kereta api memerlukan adanya ketersediaan fasilitas di stasiun KA. Jenis-jenis fasilitas yang harus disediakan oleh pihak pengelola stasiun KA adalah parkir kendaraan, loket penjualan tiket, jumlah tempat duduk, toilet, jadwal keberangkatan dan kedatangan, fasilitas konektivitas dan adanya layanan angkutan umum pengumpan di sekitar stasiun (Susanti, Soemitro \& Suprayitno, 2018). 
Ketersediaan fasilitas di stasiun KA merupakan salah satu upaya untuk menarik minat masyarakat menggunakan layanan KA. Peningkatan minat masyarakat untuk beralih menggunakan layanan KA dapat terwujud apabila kualitas pelayanan di stasiun KA dipenuhi sesuai dengan keinginan penggunanya (Eboli et al, 2016). Pergerakan perjalanan penumpang KA Komuter dari lokasi asal sampai dengan stasiun asal dan dari stasiun tujuan sampai dengan lokasi tujuan KA penting untuk diketahui guna merencanakan kebutuhan fasilitas apa saja yang perlu disediakan dengan baik di stasiun KA. Perencanaan kebutuhan fasilitas di stasiun KA tersebut membutuhkan adanya pengetahuan yang cukup mengenai perilaku perjalanan penumpang KA Komuter.

Oleh karena itu diperlukan penelitian mengenai identifikasi kebutuhan fasilitas bagi penumpang di stasiun KA berdasarkan analisa pergerakan penumpang. Tujuan dilakukannya penelitian ini adalah untuk mengetahui tipe/jenis fasilitas yang harus disediakan di stasiun KA berdasarkan pergerakan penumpang. Pergerakan penumpang KA Komuter SUSI yang diamati adalah pergerakan penumpang tiba di Stasiun Wonokromo dan pergerakan penumpang turun dari KA di Stasiun Waru.

\section{STUDI PUSTAKA}

\section{Tranportasi}

Transportasi dapat diartikan sebagai usaha memindahkan, menggerakkan, mengangkut atau mengalihkan suatu obyek dari suatu tempat ke tempat lain, dimana di tempat lain ini objek tersebut lebih bermanfaat atau atau dapat berguna untuk tujuan-tujuan tertentu (Miro, 2004). Transportasi merupakan perjalanan orang atau barang dari satu titik asal ke titik tujuan. Transportasi merupakan pusat kegiatan atau aktivitas manusia di bidang ekonomi, pendidikan, rumah tangga, sosial, olah raga, kesehatan, rekreasi dan lain-lain (Suprayitno, 2016).

Transportasi diartikan sebagai kegiatan yang melakukan pengangkutan atau pemindahan muatan (yang terdiri dari barang dan manusia) dari suatu tempat ke tempat lain, dari tempat asal (origin) ke tempat tujuan (destination). Perjalanan dari tempat asal menuju ke tempat tujuan disebut Origin Destination Travel (O-D Travel). Pada kegiatan transportasi dibutuhkan unsur-unsur dasar /utama (basic elements) terdiri dari: 1) Kendaraan/sarana angkutan (the vehicle); 2). Jalan/trayek/rute (the way); 3).Terminal/pelabuhan laut/bandara udara (the terminal); 4).Tersedianya muatan (the cargo) (Adisasmita, 2011).

\section{Definisi Stasiun Kereta Api}

Stasiun kereta api berfungsi sebagai tempat kereta api berangkat atau berhenti untuk melayani naik turun penumpang, bongkar muat barang, keperluan operasi kereta api. Stasiun kereta api untuk keperluan pengoperasian kereta api harus dilengkapi dengan fasilitas keselamatan dan kepentingan pengoperasian kereta api. Pada stasiun kereta api terdapat jasa pelayanan khusus berupa ruang tunggu penumpang, bongkar muat barang, pergudangan, parkir kendaraan, dan penitipan barang (UU RI 23/07).

Gedung stasiun Kereta Api (KA) merupakan bagian dari stasiun kereta api yang digunakan untuk melayani pengaturan perjalanan kereta api dan pengguna jasa kereta api. Jenis gedung di dalam stasiun dibagi menjadi beberapa kegiatan, yaitu: 1). Gedung untuk kegiatan pokok, 2). Gedung untuk kegiatan penunjang stasiun kereta api, 3). Gedung untuk kegiatan jasa pelayanan khusus di stasiun. Pada tiap-tiap gedung tersebut terbagi dalam beberapa ruang yang disediakan bagi penumpang kereta api dan ditunjukkan pada Tabel 1. (Permenhub 29/11). 
(e)ISSN 2615-1847 (p)ISSN 2615-1839

Jurnal Manajemen Aset Infrastruktur \& Fasilitas - Vol. 2, No. 1, Maret 2018

Tabel 1. Jenis-Jenis Gedung di Stasiun Kereta Api

\begin{tabular}{|c|c|c|}
\hline Gedung Pokok & Gedung Penunjang & Gedung Pelayanan Khusus \\
\hline $\begin{array}{l}\text { Hall, perkantoran, loket, ruang } \\
\text { tunggu, ruang informasi, ruang } \\
\text { fasilitas umum, ruang fasilitas } \\
\text { keselamatan, ruang fasilitas } \\
\text { keamanan, ruang fasilitas bagi } \\
\text { penyandang cacat, ruang } \\
\text { fasilitas ksesehatan. }\end{array}$ & $\begin{array}{l}\text { Pertokoan, } \\
\text { perkantoran, parkir, perhotelan, } \\
\text { ruang lain menuju kegiatan } \\
\text { stasiun KA. }\end{array}$ & $\begin{array}{l}\text { Ruang tunggu penumpang, } \\
\text { bongkar muat barang, } \\
\text { pergudangan, parkir kendaraan, } \\
\text { penitipan barang, ruang atm, } \\
\text { ruang lain yang menunjang baik } \\
\text { secara langsung dan tidak } \\
\text { langsung. }\end{array}$ \\
\hline
\end{tabular}

Sumber: Permenhub 29/11

\section{Fasilitas di Stasiun Kereta Api}

Pergerakan penumpang yang menuju dan meninggalkan stasiun KA dengan moda penghubung yang digunakannya membutuhkan adanya ketersediaan fasilitas taman dan parkir sebagai sarana umum sistem transit. Fasilitas taman dan parkir direncanakan berdasarkan pemilihan moda yang digunakan oleh masing-masing pelaku perjalanan. Tujuan disediakannya fasilitas taman dan parkir ini kedepannya untuk mengurangi jarak tempuh perjalanan kendaraan. Semakin banyak fasilitas taman dan parkir yang disediakan di dekat tempat pemberhentian kereta api, maka diharapkan dapat mengurangi jarak tempuh bagi pelaku perjalanan. Ketersediaan fasilitas taman dan parkir tersebut dibuat dalam beberapa alternatif perencanaan berdasarkan perilaku perjalanan (Duncan, 2014).

Permintaan kebutuhan fasilitas di stasiun KA yang terus meningkat terjadi sebagai akibat dari peningkatan pergerakan penumpang di dalam stasiun KA. Proses pergerakan penumpang mulai dari pembelian tiket sampai dengan menunggu kedatangan KA membutuhkan adanya fasilitas pejalan kaki di dalam stasiun KA seperti halnya tangga berjalan, eskalator, dan juga lift. Ketersediaan fasilitas ini sangat dibutuhkan untuk mempermudah pergerakan penumpang di dalam stasiun KA. Perencanaan terkait pengaturan fasilitas bagi pejalan kaki di dalam stasiun KA dalam hal ini Stasiun Takatsuki di Jepang dilakukan untuk menghindari terjadinya persilangan antara penumpang yang naik dan turun dari KA. Perencanaan tata letak (layout) tersebut dilakukan berdasarkan pergerakan penumpang yang ada di tiap-tiap area yang ada di dalam stasiun (Ahn et al, 2017).

Penelitian terkait ketersediaan terminal dan fasilitas pendukung lainnya di tiap-tiap stasiun yang dilalui oleh KA Komuter yang ada di Kota Surabaya dari 14 stasiun yang ada hanya 2 stasiun saja yang dekat dengan layanan terminal yaitu Stasiun Wonokromo dan Stasiun Benowo. Terkait ketersediaan fasilitas pendukung konektivitas ada beberapa stasiun yang memiliki fasilitas tersebut, yaitu Stasiun Gubeng tersedia fasilitas zebra cross, Stasiun Wonokromo tersedia fasilitas pejalan kaki dan Jembatan Penyeberangan Orang (JPO), Shelter Jemursari tersedia fasilitas JPO, Shelter Kertomenanggal tersediat fasilitas JPO, Stasiun Waru tersedia fasilitas JPO, Stasiun Pasar Turi tersedia fasilitas pejalan kaki, Stasiun Tandes tersedia fasilitas pelican crossing, Stasiun Benowo tersedia fasilitas pelican crossing, dan Stasiun Benowo tersedia fasilitas pelican crossing (Susanti, Soemitro \& Suprayitno, 2017).

Pengukuran kualitas pelayanan di dalam stasiun KA berdasarkan persepsi pengguna perlu dilakukan dengan tujuan untuk mengetahui faktor-faktor yang paling berpengaruh terhadap kepuasan pengguna. Hasil pengukuran kualitas pelayanan diketahui ada delapan (8) faktor yang berpengaruh terhadap kepuasan pengguna yaitu: 1). Sikap petugas stasiun, 2). Kebersihan stasiun, 3). Pemeliharaan stasiun, 4). Sistem perpindahan yang terintegrasi, 5) Fasilitas bagi penyandang cacat, 6). Informasi di stasiun, 7). Informasi jadwal terkait dengan layanan angkutan umum lainnya, 8). Kualitas layanan transit secara keseluruhan (Eboli, 2018). 


\section{PENGUMPULAN DATA}

Metode yang digunakan pada penelitian ini adalah pengumpulan data primer berupa observasi atau pengamatan langsung di stasiun. Pengumpulan data primer dilakukan oleh penulis dengan melakukan perjalanan menggunakan layanan KA Komuter Surabaya-Sidoarjo (SUSI). Penulis melakukan perjalanan untuk melakukan pengamatan pergerakan penumpang KA Komuter SUSI pada pukul 12.48 tanggal 10 Februari 2018. Kegiatan pengamatan pergerakan penumpang KA Komuter SUSI dilakukan dengan cara mendokumentasikan pergerakan ke dalam bentuk gambar foto. Hasil dokumentasi berupa gambar foto tersebut dijadikan dasar untuk mengetahui tipe fasilitas yang harus disediakan di stasiun KA berdasarkan pergerakan penumpang KA Komuter. Pergerakan penumpang KA Komuter yang diamati yaitu pergerakan tiba di stasiun Wonokromo sebagai stasiun naik dan pergerakan turun di Stasiun Waru sebagai stasiun turun.

\section{ANALISIS PENELITIAN}

\section{Hasil Pengamatan Pergerakan Penumpang Kereta Api Komuter}

Hasil pengamatan pergerakan penumpang yang kemudian di dokumentasikan berupa gambar foto meliputi beberapa hal sebagai berikut: 1). Ketersediaan jembatan penyeberangan orang di sekitar Stasiun Wonokromo ditunjukkan pada Gambar 1a, 2). Ketersediaan fasilitas bagi pejalan kaki di sekitar Stasiun Wonokromo ditunjukkan pada Gambar 1b, 3). Ketersediaan parkir kendaraan baik roda dua dan roda empat di Stasiun Wonokromo ditunjukkan pada Gambar 1c, 4). Penumpang turun dari mikrolet di depan Stasiun Wonokromo ditunjukkan pada Gambar 1d, 5). Penurunan penumpang oleh taksi online di depan Stasiun Wonokromo ditunjukkan pada Gambar 1e, 6). Proses pembelian tiket KA di loket yang ada di Stasiun Wonokromo ditunjukkan pada Gambar 1f, 7). Proses pemeriksaan tiket KA di Stasiun Wonokromo ditunjukkan pada Gambar 1g, 8). Proses menunggu kedatangan KA di Stasiun Wonokromo ditunjukkan pada Gambar 1h, 9). Penumpang naik KA di Stasiun Wonokromo ditunjukkan pada Gambar 1i.

Dokumentasi di dalam KA Komuter SUSI juga dilakukan dan ditunjukkan pada Gambar 1j. Dokumentasi di Stasiun Waru sebagai stasiun tujuan meliputi beberapa hal sebagai berikut: 1). Proses penumpang turun dari KA Komuter di Stasiun Waru ditunjukkan pada Gambar 1k, 2). Kondisi pintu keluar di Stasiun Waru ditunjukkan pada Gambar 11. 3). Kondisi parkir kendaraan roda dua di Stasiun Waru ditunjukkan pada Gambar 1m, 4). Tidak tersedia parkir kendaraan roda empat di Stasiun Waru ditunjukkan pada Gambar 1n, 5). Ketersediaan fasilitas jembatan penyeberangan orang di dekat Stasiun Waru ditunjukkan pada Gambar 1o, 6). Kondisi trotoar di sekitar Stasiun Waru ditunjukkan pada Gambar 1p, 7). Ketersediaan layanan mikrolet di sekitar Stasiun Waru ditunjukkan pada Gambar 1q, 8). Ketersediaan layanan gojek di sekitar Stasiun Waru ditunjukkan pada Gambar 1r. Hasil Gambar foto kondisi yang ada berdasarkan pergerakan penumpang KA komuter SUSI secara keseluruhan baik di Stasiun Wonokromo maupun di Stasiun Waru ditunjukkan pada Gambar 1. 

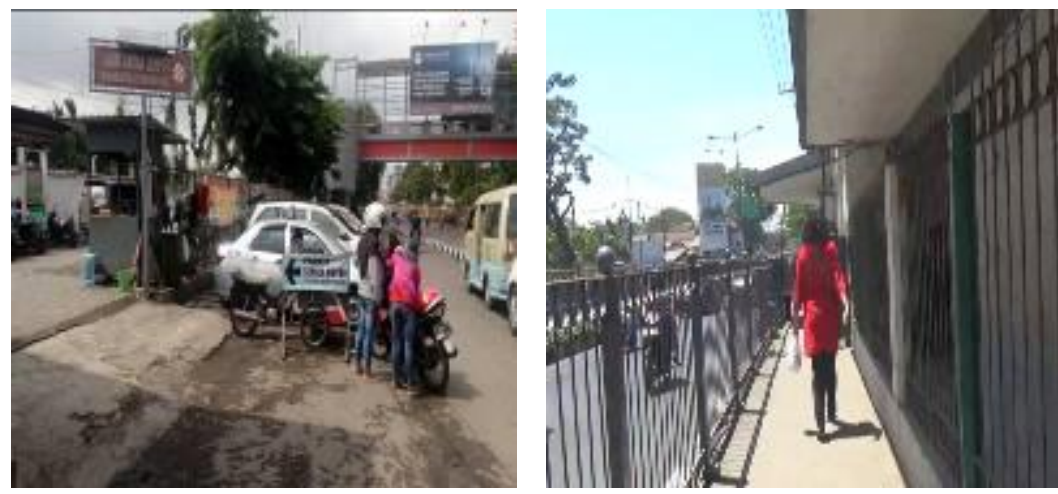

Gambar 1a. Foto fasilitas jembatan penyeberangan orang di Stasiun Wonokromo.

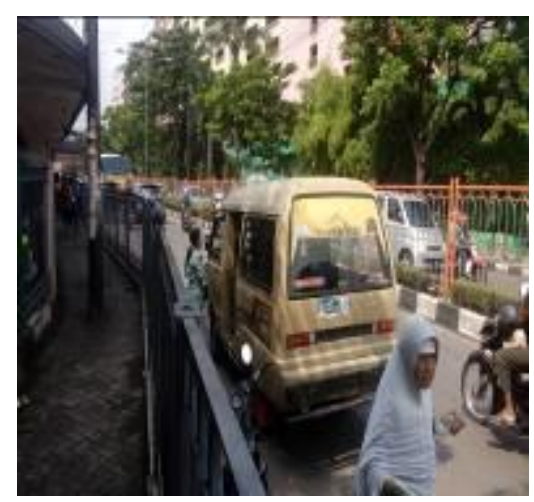

Gambar 1d. Foto penumpang turun dari mikrolet di depan Stasiun Wonokromo.

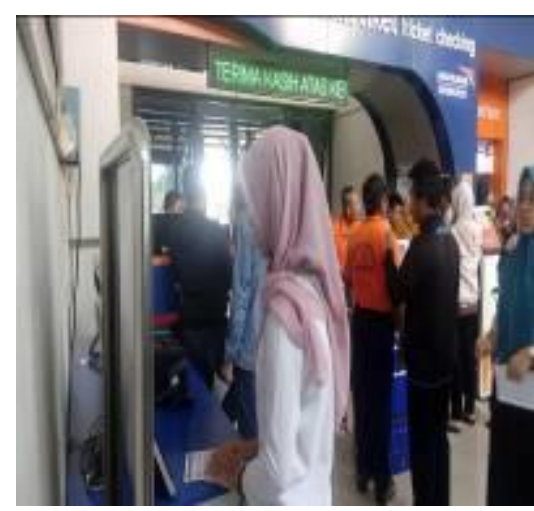

Gambar 1g. Foto pemeriksaan tiket sebelum menuju ke kereta api komuter Di Stasiun Wonokromo.
Gambar 1b. Foto fasilitas pejalan kaki dari terminal menuju ke Stasiun Wonokromo.

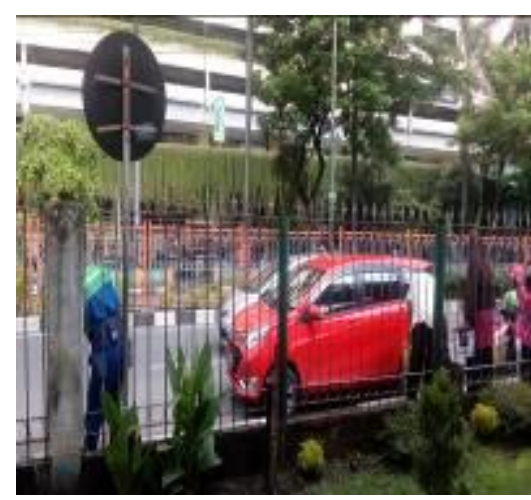

Gambar 1e. Foto pengantar penumpang menggunakan mobil

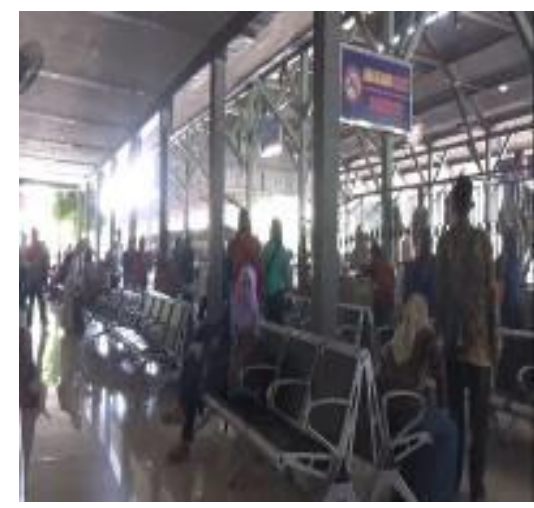

Gambar 1h. Foto ruang tunggu penumpang sebelum naik ke kereta api komuter di Stasiun Wonokromo. berhenti di pinggir jalan.

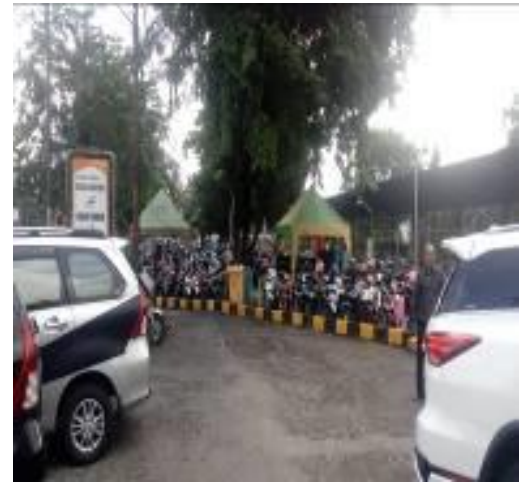

Gambar 1c. Foto parkir kendaraan roda 2 dan roda 4 di Stasiun Wonokromo.

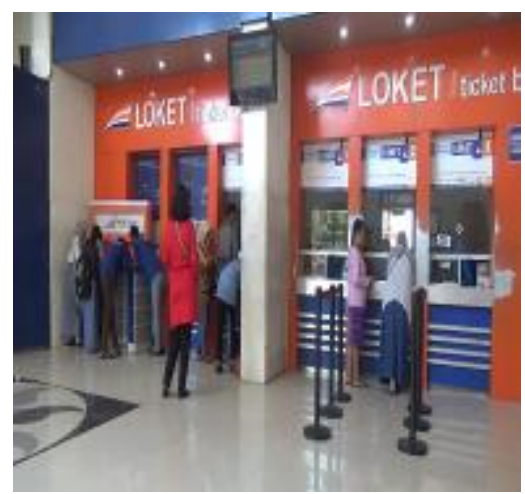

Gambar 1f. Foto loket no. 4 merupakan loket Go Show yang melayani perjalanan KA Komuter.

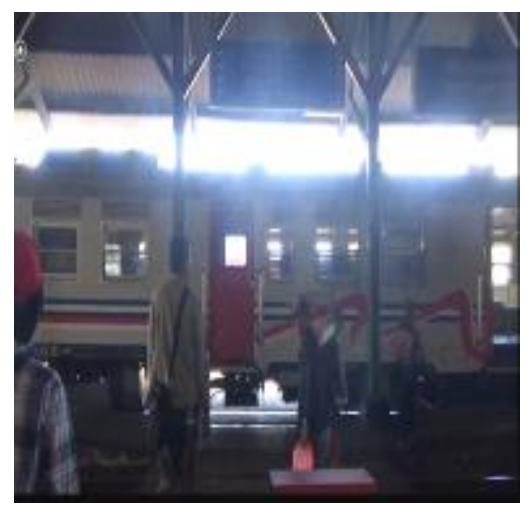

Gambar 1i. Foto Penumpang naik ke dalam kereta api komuter di Stasiun Wonokromo. 


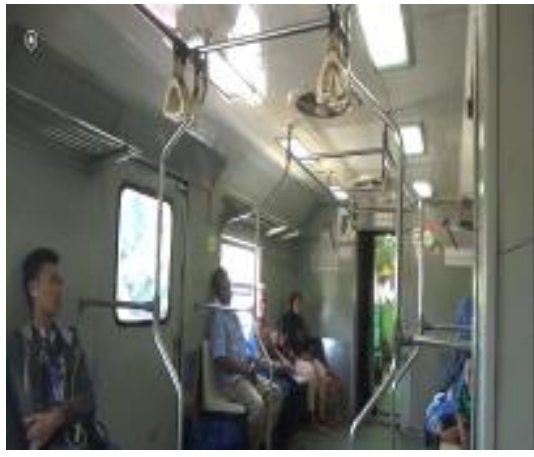

Gambar 1j. Foto penumpang di dalam kereta api komuter Surabaya-Sidoarjo.

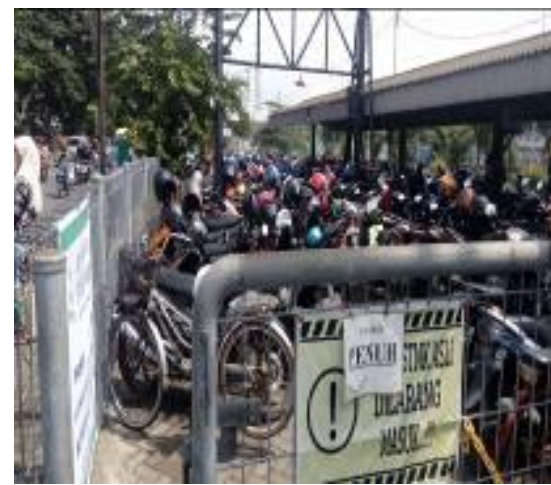

Gambar 1m. Foto parkir kendaraan roda dua di Stasiun Waru.

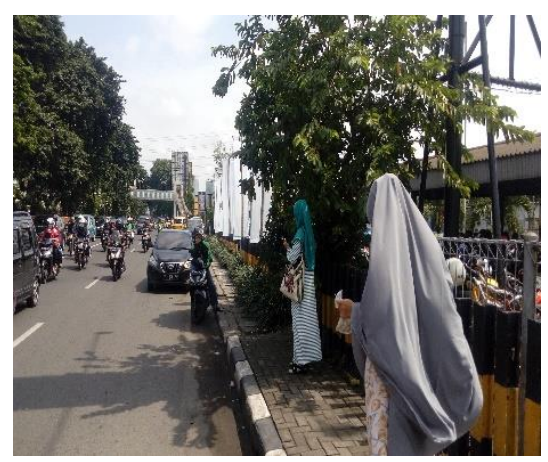

Gambar 1p. Foto kondisi trotoar yang ada di sekitar Stasiun Waru

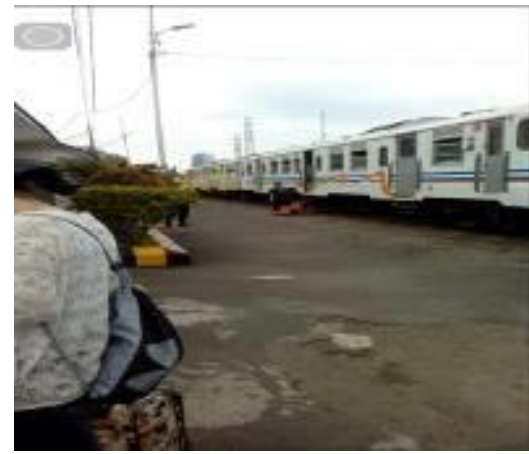

Gambar 1k. Foto penumpang turun dari kereta api komuter di Stasiun Waru

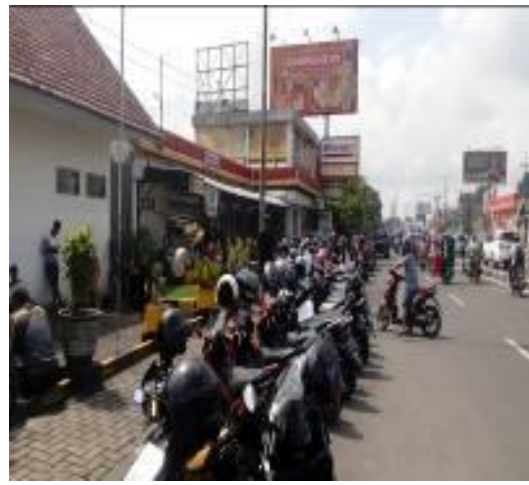

Gambar 1n. Foto tidak tersedia parkir kendaraan roda empat di Stasiun Waru.

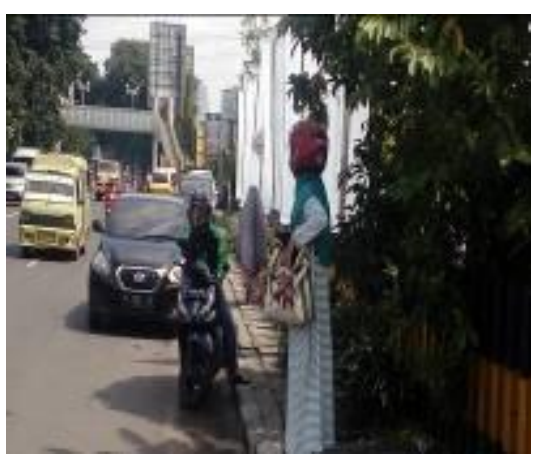

Gambar 1q. Foto tersedia layanan mikrolet yang melintas di depan Stasiun Waru.

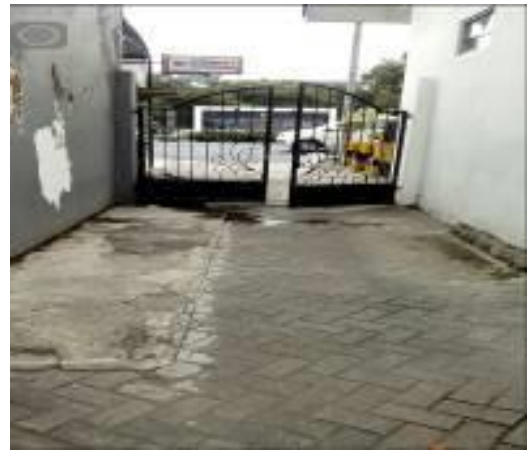

Gambar 11. Foto pintu keluar di Stasiun Waru bagi penumpang yang turun dari kereta api.

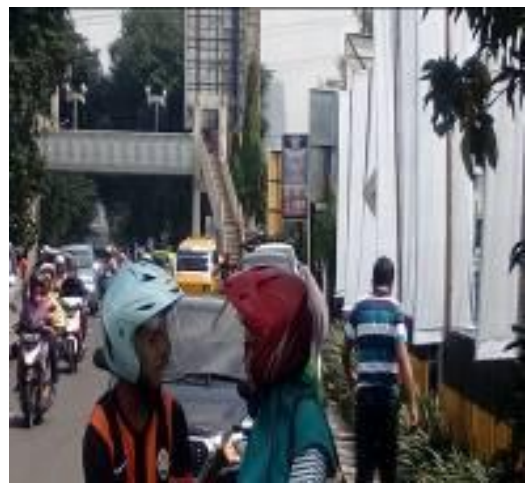

Gambar 1o. Foto tersedia jembatan penyeberangan orang di dekat Stasiun Waru.

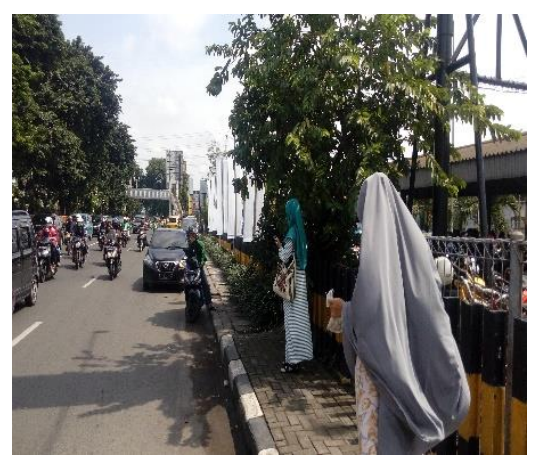

Gambar 1r. Foto layanan gojek di sekitar Stasiun Waru.

Gambar 1. Foto Kondisi yang ada di Stasiun Wonokromo (Stasiun Asal) dan di Stasiun Waru (Stasiun Tujuan)

\section{Proses Pergerakan Penumpang KA Komuter}

Pada penelitian ini dilakukan pengamatan pergerakan penumpang KA Komuter SUSI di dua tempat, yaitu: 1). Stasiun Wonokromo sebagai stasiun naik 2). Stasiun Waru sebagai stasiun turun. Pengamatan untuk mengetahui kebutuhan fasilitas di stasiun KA hanya fokus pada pergerakan penumpang di stasiun asal dan di stasiun tujuan saja. Proses pergerakan 
penumpang KA Komuter SUSI berdasarkan hasil pengamatan secara umum ditunjukkan pada Gambar 2.

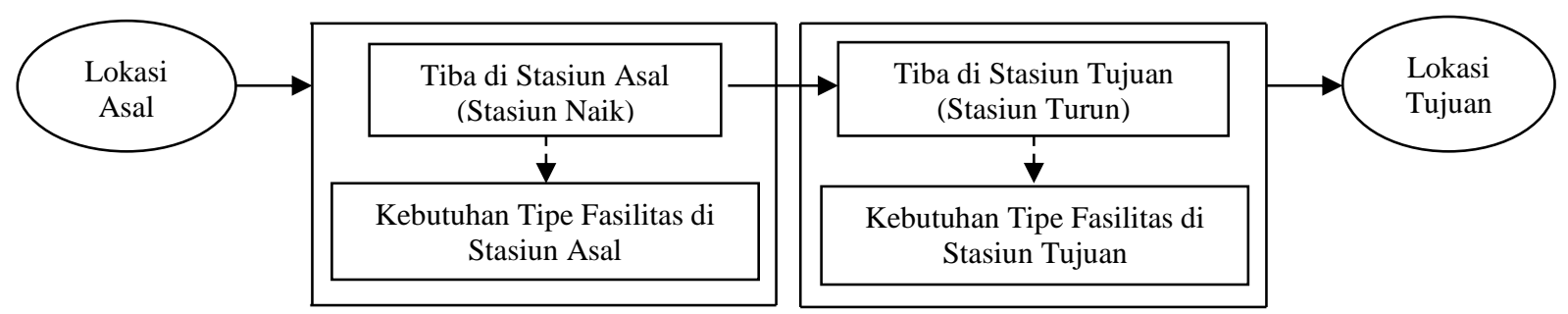

Gambar 2. Proses Pergerakan Penumpang KA Komuter SUSI

\section{Tahapan Pergerakan Penumpang KA Komuter}

Pergerakan penumpang KA Komuter SUSI dapat dibagi lagi menjadi beberapa tahapan kegiatan mulai tiba di stasiun asal sampai dengan meninggalkan stasiun tujuan. Tahapan pergerakan penumpang KA Komuter SUSI berdasarkan pengamatan langsung di stasiun KA meliputi beberapa hal-hal sebagai berikut dan ditunjukkan pada Gambar 3:

a Pergerakan penumpang di stasiun asal dibagi lagi menjadi beberapa tahapan, yaitu: 1). Proses tiba di stasiun asal dengan berjalan kaki, sepeda motor, mobil, angkutan umum. Penumpang yang berjalan kaki menuju stasiun asal membutuhkan adanya fasilitas penyeberangan, trotoar, dan fasilitas bagi pejalan kaki. Penumpang yang menggunakan sepeda motor dan mobil dengan cara dibawa sendiri membutuhkan fasilitas parkir kendaraan. Penumpang yang menggunakan sepeda motor dan mobil dengan cara diantar membutuhkan fasilitas drop zone. Penumpang yang menggunakan angkutan umum (taksi dan online) membutuhkan fasilitas drop zone dan bus stop. Penumpang yang menggunakan angkutan umum (mikrolet dan bus kota) membutuhkan fasilitas bus stop; 2). Proses pembelian tiket KA membutuhkan adanya loket, tempat duduk, toilet, dan hall; 3). Proses pemeriksaan tiket KA membutuhkan adanya fasilitas pintu masuk dan petugas; 4). Proses menunggu kedatangan KA membutuhkan adanya fasilitas tempat duduk, toilet, kantin, mushola, charger, hall, peron, tangga naik ke KA.

b Pergerakan penumpang di stasiun tujuan dibagi menjadi beberapa tahapan, yaitu: 1). Proses turun dari KA membutuhkan fasilitas tangga turun dari KA, peron, toilet, pintu keluar, hall.; 2). Proses keluar dari stasiun KA dengan berjalan kaki untuk mendapatkan moda berikutnya membutuhkan fasilitas bagi pejalan kaki, trotoar dan fasilitas penyeberangan. Penumpang yang menggunakan sepeda motor dan mobil dengan cara dibawa sendiri membutuhkan fasilitas parkir kendaraan. Penumpang yang menggunakan sepeda motor dan mobil dengan cara dijemput membutuhkan fasilitas parkir khusus bagi penjemput, embarking. Penumpang yang menggunakan angkutan umum (taksi dan online) membutuhkan fasilitas parkir khusus bagi penjemput, fasilitas parkir khusus taksi (taksi stand), fasilitas parkir khusus gojek (gojek stand). Penumpang yang menggunakan angkutan umum (mikrolet dan bus kota) membutuhkan fasilitas bus stop. 
(e)ISSN 2615-1847 (p)ISSN 2615-1839

Jurnal Manajemen Aset Infrastruktur \& Fasilitas - Vol. 2, No. 1, Maret 2018

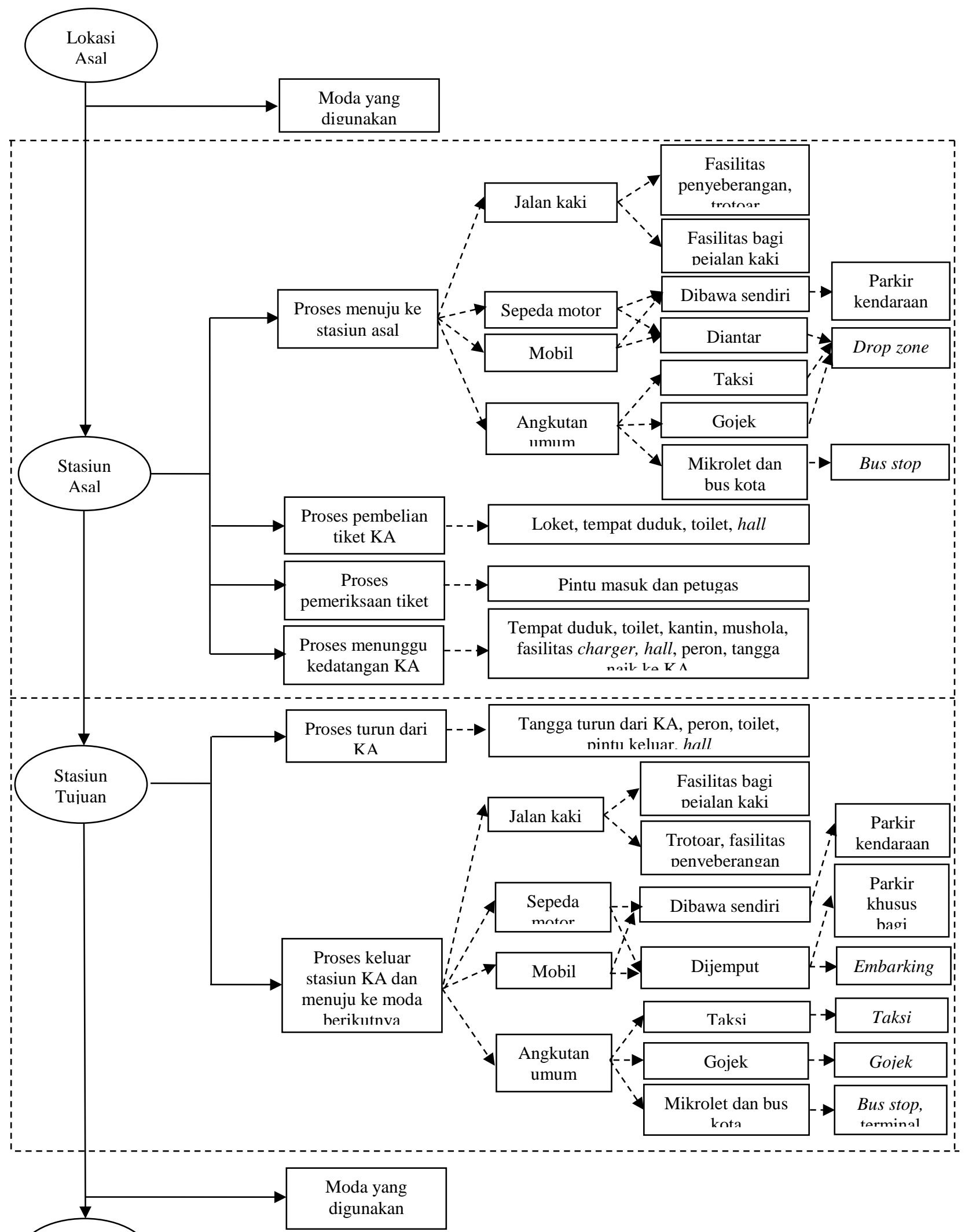

Lokasi

Gambar 3. Tahapan Pergerakan Penumpang KA

Komuter dari Lokasi Asal sampai dengan Lokasi Tujuan 


\section{Kebutuhan Fasilitas di Stasiun KA Berdasarkan Pergerakan Penumpang KA Komuter}

Kebutuhan tipe fasilitas di stasiun KA berdasarkan pergerakan penumpang ada yang disediakan di dalam dan di luar stasiun. Perbedaan keberadaan terkait ketersediaan fasilitas tersebut didasarkan pada tiap tahapan pergerakan penumpang. Kebutuhan tipe fasilitas tersebut didasarkan pada tahapan kegiatan di stasiun asal (stasiun naik) dan tahapan kegiatan di stasiun tujuan (stasiun turun) dan ditunjukkan pada Tabel 2.

Tabel 2. Kebutuhan Fasilitas di Stasiun KA Berdasarkan Pergerakan Penumpang KA Komuter

\begin{tabular}{|c|c|c|c|c|}
\hline No. & Tahapan & Uraian & $\begin{array}{c}\text { Kebutuhan Tipe Fasilitas di } \\
\text { Stasiun KA }\end{array}$ & Lokasi Fasilitas \\
\hline \multirow{5}{*}{1.} & \multirow{5}{*}{$\begin{array}{l}\text { Kegiatan di } \\
\text { stasiun asal } \\
\text { (Stasiun naik) }\end{array}$} & \multirow{2}{*}{$\begin{array}{l}\text { Proses menuju ke } \\
\text { stasiun asal }\end{array}$} & $\begin{array}{l}\text { Fasilitas penyeberangan, } \\
\text { trotoar, bus stop. }\end{array}$ & $\begin{array}{l}\text { Lokasi di luar area } \\
\text { stasiun asal KA }\end{array}$ \\
\hline & & & $\begin{array}{l}\text { Fasilitas bagi pejalan kaki, } \\
\text { drop zone, tempat parkir } \\
\text { kendaraan. }\end{array}$ & $\begin{array}{l}\text { Lokasi di dalam area } \\
\text { stasiun asal KA }\end{array}$ \\
\hline & & $\begin{array}{l}\text { Proses pembelian } \\
\text { tiket KA }\end{array}$ & $\begin{array}{l}\text { Fasilitas loket, tempat duduk, } \\
\text { toilet, hall }\end{array}$ & $\begin{array}{l}\text { Lokasi di dalam area } \\
\text { stasiun asal KA }\end{array}$ \\
\hline & & $\begin{array}{c}\text { Proses } \\
\text { pemeriksaan tiket } \\
\text { KA }\end{array}$ & $\begin{array}{c}\text { Fasilitas pintu masuk dan } \\
\text { petugas pemeriksa tiket KA }\end{array}$ & $\begin{array}{l}\text { Lokasi di dalam area } \\
\text { stasiun asal KA }\end{array}$ \\
\hline & & Proses naik KA & $\begin{array}{l}\text { Loket, tempat duduk, toilet, } \\
\text { pintu masuk, kantin, mushola, } \\
\text { charger, hall, peron, tangga } \\
\text { naik ke KA }\end{array}$ & $\begin{array}{l}\text { Lokasi di dalam area } \\
\text { stasiun asal KA }\end{array}$ \\
\hline \multirow{3}{*}{2.} & \multirow{3}{*}{$\begin{array}{l}\text { Kegiatan di } \\
\text { stasiun tujuan } \\
\text { (stasiun turun) }\end{array}$} & $\begin{array}{l}\text { Proses turun dari } \\
\text { KA }\end{array}$ & $\begin{array}{l}\text { Tangga turun dari KA, peron, } \\
\text { toilet, tempat duduk, hall. }\end{array}$ & $\begin{array}{l}\text { Lokasi di dalam area } \\
\text { stasiun tujuan KA }\end{array}$ \\
\hline & & \multirow[t]{2}{*}{$\begin{array}{l}\text { Proses menuju } \\
\text { keluar dari } \\
\text { stasiun KA }\end{array}$} & $\begin{array}{l}\text { Fasilitas bagi pejalan kaki, } \\
\text { tempat parkir kendaraan, } \\
\text { tempat parkir khusus bagi } \\
\text { penjemput, embarking, taksi } \\
\text { stand, gojek stand }\end{array}$ & $\begin{array}{l}\text { Lokasi di dalam area } \\
\text { stasiun tujuan KA }\end{array}$ \\
\hline & & & $\begin{array}{c}\text { Trotoar, fasilitas } \\
\text { penyeberangan, bus stop, } \\
\text { terminal. }\end{array}$ & $\begin{array}{l}\text { Lokasi di luar area } \\
\text { stasiun tujuan KA }\end{array}$ \\
\hline
\end{tabular}

Sumber: Hasil analisis, 2018

\section{KESIMPULAN}

Pergerakan penumpang KA Komuter SUSI mulai tiba di stasiun asal sampai dengan turun di stasiun tujuan menghasilkan beberapa hal sebagai berikut:

- Kebutuhan tipe fasilitas berdasarkan pergerakan penumpang di stasiun asal sebagai stasiun naik, menghasilkan beberapa hal sebagai berikut:

○ Proses menuju ke stasiun asal berdasarkan moda yang digunakan dibedakan menjadi beberapa hal sebagai berikut:

$>$ Proses menuju ke stasiun asal dengan berjalan kaki, sepeda motor, mobil, angkutan umum membutuhkan adanya tipe fasilitas seperti halnya fasilitas penyeberangan, fasilitas trotoar, fasilitas bus stop yang harus disediakan di luar area stasiun KA.

$>$ Proses menuju ke stasiun asal dengan berjalan kaki, sepeda motor, mobil, angkutan umum membutuhkan adanya tipe fasilitas seperti halnya fasilitas bagi pejalan kaki, fasilitas parkir kendaraan roda dua dan roda empat, dan fasilitas drop zone yang harus disediakan di dalam area stasiun KA. 
○ Proses pembelian tiket KA membutuhkan adanya fasilitas loket, fasilitas tempat duduk, fasilitas toilet yang harus disediakan di dalam area stasiun KA.

o Proses pemeriksaan tiket KA membutuhkan adanya fasilitas pintu masuk dan petugas yang harus disediakan di dalam area stasiun KA.

○ Proses menunggu kedatangan KA membutuhkan adanya fasilitas tempat duduk, fasilitas toilet, fasilitas kantin, fasilitas mushola, fasilitas charger, fasilitas hall, peron, fasilitas tangga naik ke KA yang harus disediakan di dalam area stasiun KA.

- Kebutuhan fasilitas berdasarkan pergerakan penumpang di stasiun tujuan sebagai stasiun turun, menghasilkan beberapa hal sebagai berikut:

- Proses turun dari KA membutuhkan tipe fasilitas seperti halnya fasilitas tangga turun dari KA, peron, fasilitas toilet, fasilitas pintu keluar, fasilitas hall yang harus disediakan di dalam area stasiun KA.

○ Proses keluar dari stasiun tujuan berdasarkan moda yang digunakan dibedakan menjadi beberapa hal sebagai berikut:

$>$ Proses meninggalkan stasiun tujuan dengan berjalan kaki, sepeda motor, mobil, angkutan umum membutuhkan adanya tipe fasilitas seperti halnya fasilitas bagi pejalan kaki, fasilitas parkir kendaraan, fasilitas parkir khusus bagi penjemput, embarking, fasilitas parkir khusus taksi (taksi stand), fasilitas parkir khusus gojek (gojek stand) yang harus disediakan di dalam area stasiun KA.

$>$ Proses meninggalkan stasiun tujuan dengan berjalan kaki, sepeda motor, mobil, angkutan umum membutuhkan adanya tipe fasilitas seperti halnya fasilitas trotoar, fasilitas penyeberangan, fasilitas bus stop, dan fasilitas terminal yang harus disediakan di luar area stasiun KA.

Hasil penelitian diketahui bahwa kebutuhan tipe fasilitas yang harus disediakan baik di dalam maupun di luar area stasiun KA berdasarkan pergerakan penumpang KA Komuter. Oleh karena itu diperlukan penelitian lanjutan mengenai penilaian dan pengukuran kebutuhan tipe fasilitas di stasiun KA berdasarkan dari pendapat penumpang KA Komuter SUSI.

CATATAN. Penelitian ini dilakukan dengan cara pengamatan langsung di Stasiun Wonokromo sampai dengan Stasiun Waru terkait dengan pergerakan penumpang KA Komuter Surabaya-Sidoarjo arah Surabaya-Porong di jam keberangkatan siang hari. Hasil pengamatan dijadikan dasar untuk mengetahui kebutuhan fasilitas bagi penumpang di stasiun KA.

\section{DAFTAR PUSTAKA}

Adisasmita, S.A. (2011). Jaringan Transportasi - Teori dan Analisis. Penerbit Graha Ilmu. Yogyakarta.

Ahn, Y., Kowada, T., Tsukaguchi, H. \& Vandebona, U. (2017). "Estimation of Passenger Flow for Planning and Management of Railway Stations". Transportation Research Procedia, 25, pp. 315-330. World Conference on Transport Research. Shanghai.

Duncan, M. \& Cook, D. (2014). "Is the provision of park-and-ride facilities at light rail stationa an effective approach to reducing vehicle kilometers traveled in a US context?". Transportation Research Part A, 66, pp. 65-74.

Eboli, L., Fu, Y. \& Mazzula, G. (2016). "Multilevel Comprehensive Evaluation of The Railway Service Quality”. Procedia Enggineering, 137, pp. 21-30.

Eboli, L., Forciniti, C. \& Mazzula, G. (xxxx). "Spatial variation of the perceived transit service quality at rail stations". Transportation Research Part A, xxx, pp. xxx.

Miro, F. (2004). Perencanaan Transportasi. Penerbit Erlangga. Jakarta. 
Permen Perhubungan 29/11 (2011). Peraturan Menteri Perhubungan No 29 Tahun 2011 tentang Persyaratan Teknis Bangunan Stasiun Kereta Api. Menteri Perhubungan Republik Indonesia. Jakarta.

Suprayitno, H. (2016), "A Basic Framework For Regarding A Transportation System". Prosiding Seminar Nasional Teknik Sipil XII, 28 Januari, halaman 240-249. Program Studi Pascasarjana. Jurusan Teknik Sipil. FTSP ITS. Surabaya.

Susanti, A., Soemitro, R.A.A. \& Suprayitno, H. (2017). "Identifikasi Awal Layanan Feeder di Tiap-Tiap Stasiun Pemberhentian KA Penumpang di Kota Surabaya”. E-Journal Rekayasa Teknik Sipil (REKATS) UNESA, Vol. 1, No. 1, halaman 439-445.

Susanti, A., Soemitro, R.A.A. \& Suprayitno, H. (2018). "Metoda Simulasi Bagi Perhitungan Kebutuhan Jumlah Tempat Duduk Pada Fasilitas Reservasi Tiket KA". Jurnal Manajemen Aset Infrastruktur \& Fasilitas, Vol. 1, No.1, halaman 23-32. Institut Teknologi Sepuluh Nopember (ITS). Surabaya. 
(e)ISSN 2615-1847 (p)ISSN 2615-1839

Jurnal Manajemen Aset Infrastruktur \& Fasilitas - Vol. 2, No. 1, Maret 2018 